\title{
FÉNYERŐSSÉG STABILIZÁLÁSA AZ iROOM LABORATÓRIUMBAN
}

\section{LUMINOUS INTENSITY STABILIZATION IN THE IROOM LABORATORY}

\author{
Vanessa Tinami Tamashiro ${ }^{1}$, Gabriel Galperin ${ }^{2}$, Marcus Vinicius Silva De \\ Sant'Ana ${ }^{3}$, Nagy István \\ ${ }^{1}$ Universidade Federal do ABC, UFABC, Adresse: 09210-180, Brazil, Santo André, \\ Rua Abolição, s/n; Telephone: +55 (11) 4996-0000, email address: \\ tamashiro.vanessa@outlook.com \\ ${ }^{2}$ Universidade Tecnológica Federal do Paraná, DAELT, Adress: 80.230-901, Bra- \\ zil,Curitiba, Av. Sete de Setembro, 3165; Telephone: +55(041)3310-4626, email \\ adress,gabrielgalperin@gmail.com \\ ${ }^{3}$ Universidade Federal de Pernambuco, DEMEC, Adresse: 50670-901, Brazil, Reci- \\ fe, Av. Prof. Moraes Rego, 1235; marcus_vsst@hotmail.com \\ ${ }^{4}$ Óbudai Egyetem, BGK-MEI, 1081 Budapest, Népszínház u.8, +36 1 6665366, \\ nagy.istvan@bgk.uni-obuda.hu
}

\begin{abstract}
In this paper a part of a bigger project will be introduced. The task is the luminosity stabilization and regulation of an intelligent laboratory (iRoom). Considering the other intelligent devices, acting in the intelligent laboratory (mobile robot equipped with a camera), to the proper operation we need correct luminosity. To reach this task, firstly we have to define the "darkest" point of the iRoom, locate here a photometer with special calibration for color correction factor, then establish the locations of the lights, design the regulation process for the luminosity stabilization. The first (natural) light-source is the window, where the light intensity (during the daylight) will be regulated by the curtain moving, and the others are the LED light stripes, located on the ceiling of the iRoom, which light intensity will be regulated by a special amplifier, developed by us. The final task is harmonizing the regulations in such a way, that the luminosity in the laboratory, in spite of outer light disturbances, has to remain stable.
\end{abstract}

Keywords: curtain moving automation, light sensing, camera calibration.

\section{Összefoglalás}

Ebben a cikkben egy nagyobb projekt részfeladatának bemutatására kerül sor. A cél egy intelligens szoba (iRoom) megvilágításának, fényerejének stabilizálása, és automatikus beállításának megtervezése. A fényerő stabilitása fontos a többi, projektben szereplö berendezés (kamerával ellátott mobilrobot) helyes müködéséhez. A cél elérésének érdekében elöször meghatározzuk az intelligens laboratórium „legsötétebb” pontját, itt elhelyezünk egy speciális érzékenységü fényméröt, megállapítjuk a fényforrások helyzetét, majd megtervezzük a fényerősség szabályzását. Az egyik (természetes) fényforrás az ablak, aminek fényáteresztő képességét egy függönnyel szabályozzuk, a többi fényforrás pedig a laboratórium plafonján elhelyezett LED fénycsíkok, melyeknek fényerejét egy erősítő segítségével szabályozzuk. A feladat a függöny és a fényforrás szabályozása oly módon, hogy a teremben a fényerö állandó maradjon a külső zavaró tényező hatásának ellenére.

Kulcsszavak: függöny mozgatás automatizálása, fényérzékelés, kamerakalibrálás. 


\section{Introduction, System Descrip- tion}

By the displacing of the proper amount of adequate sensors in the space, any welldefined (outdoor/indoor) environment can be extended to an Intelligent Space or Intelligent Room (iRoom) [1], [2]. The displaced sensors: cameras, thermometers, photometers, action detectors, etc., collecting the information about the space and sending them to the Central Computer Unit (CCU) for processing. As the result of processing the different actuators, e.g. mobilerobot, curtain moving mechanism, LEDstripes' control unit, etc., receiving the tasks to be executed. The functional architecture of the system can be seen on Fig. 1.

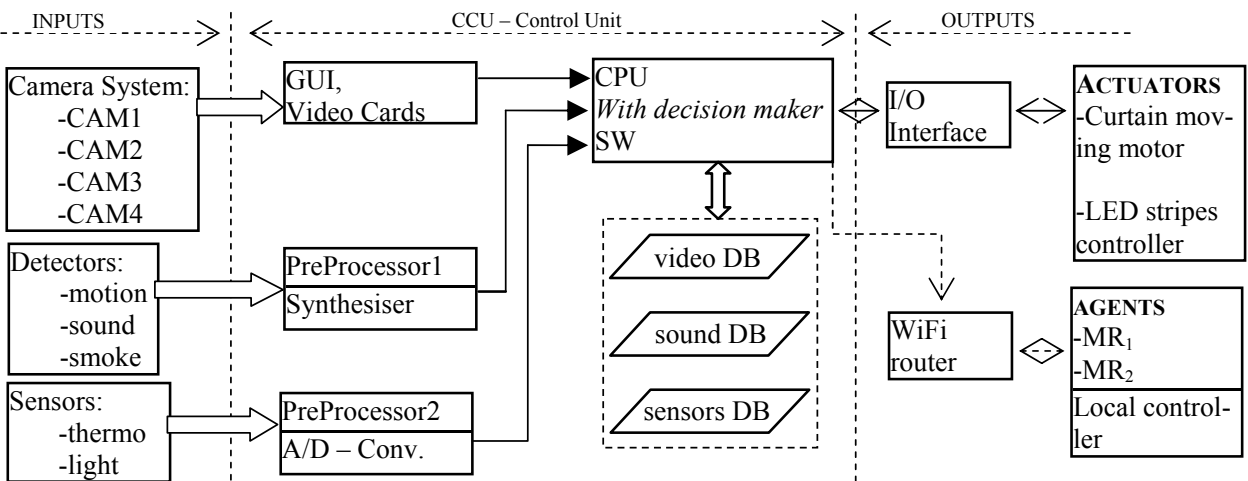

Fig. 1. The Functional Architecture of the System

The camera system consists of 4 cameras located at the four corners on the ceiling. The location of the cameras, and the distances between them have to be well known, because these dates are serving as base for the position calculation of the objects (e.g.: $\mathrm{MR}_{1}, \mathrm{MR}_{2}$ ) situated on the floor of iRoom. The "Robotino" ${ }^{\circledR}$ " mobile robots $\left(\mathrm{MR}_{1}, \mathrm{MR}_{2}\right)$ have their own local control units where the path planning algorithms are preprogrammed, but the tasks and coordinates (starting and goal) have been received from CCU. A typical task for MRs can be: find the red colored object (with the given shape and contours) in the space and take to the predetermined position in the space. In this case, the orally given command is preprocessed by PreProcessor 1 , then from $D B \mathrm{~s}$ is selected the task assigned to this command (to be executed), and together with the actual position of the MR is sent to the MR for executing. The selected MR, equipped by camera, firstly looks for a selected object and if the robot finds it, then the object's position will be marked as goal position, if the mobile-robot doesn't find the object, the MR will change the position and the procedure will be repeated from the 'search for object' sub-task. Here is that point where the stabile light intensity of the iRoom is important, because MRs' cameras can distinguish the colors just in given, well defined color and light range.

\section{Project Description}

The given task consists on ensuring the stability of luminosity in an optimal way. This process, as described above, is responsible for controlling the light intensity of the room, and provides optimal condition of operation for the four cameras located in the room, and the camera used by 
the MR in order to find objects of different colors and shades.

In order to accomplish this stability, it is used two different light sources. The first one is the filtered natural sunlight, provided through a window. Luminosity of this source is regulated using the movement of curtain, allowing the passage of the light according to the light intensity supplied by daylight.

The second light source is provided by three LED stripes located in the central part of the ceiling, and in order to avoid energy waste, will just be activated when the optimal value cannot be reached just by the first light source. This control will be realized using an encoder connected to the curtain motor.

However, for the work of this control system and the cameras, a minimal amount of light might be available in every point of the room. Considering that the light source are incapable of distribute a homogeneous light intensity, and an object can be located in a point with less luminosity, the light sensor must be located in the darkest point of the room, ensuring that itself, and by consequence, all others have at least the minimal light intensity to work properly.

\subsection{Finding the Darkest Point}

The darkest point, as presented previously, is where the light sensor will be located. In order to locate this position, it is necessary to assume full luminosity exposure. For that, it is necessary to work with both light sources, the totally open window; and LED stripes feed with nominal power.

Using the Heavy Duty Light Meter with PC Interface of Extech Instruments, is possible to find the darkest point of the room, and after that, it can be also used as light sensor, once it has PC connection.

\subsection{LED-stripes Description}

The three LED strips are ColorBright ${ }^{\mathrm{TM}}$ Natural White LED stripe light and have the following specifications, see Table 1.

Table 1. Specifications of the LED-stripes

\begin{tabular}{|l|l|}
\hline Color Temperature & $4000-4500 \mathrm{~K}$ \\
\hline Brightness (Lumen) & $280 /$ foot \\
\hline Working Voltage & 12 VDC \\
\hline Bean Angle & 120 Degrees \\
\hline Power Consumption & 2.9 Watt/foot \\
\hline $\begin{array}{l}\text { Color Rendering } \\
\text { Index (CRI) }\end{array}$ & $80+$ \\
\hline
\end{tabular}

According to these specifications there is a good rate of brightness produced by Watt, and the angle of 120 degrees makes a good distribution inside the room, avoiding extremely dark points. Another important feature is the high CRI that makes the colors look as lightened by natural light, avoiding problems with color recognition if compared to the daylight.

\subsection{Light Sensor Description and Cali- bration}

As said previously, the same light meter used to identify the darkest point, can also be used as a sensor, once it can be connected directly to a computer by a RS232 serial port.

It also has a $3 \frac{1}{2}$ LCD display, and a selection of four different light sources in order to gain better accuracy of the measured luminosity.

However, once this project uses a daylight source, and LED stripes, just one of the possible modes will be used.

\subsection{Robotino's Camera Description}

The Robotino's camera parameters can be found in Robtino's User Manual from which the most important dates are the color depth, and resolution. 


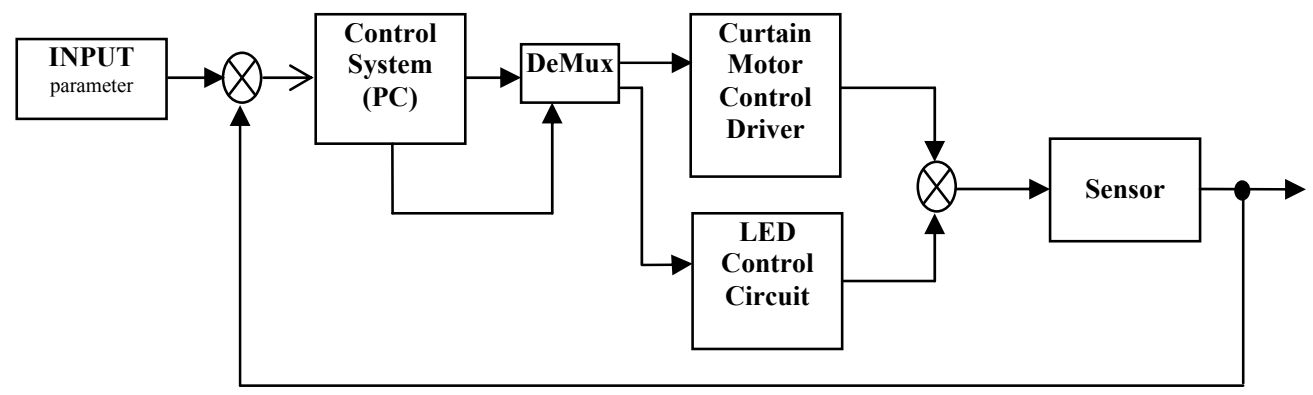

Fig. 2. The Block Diagram of the Light intensity Stabilization

These dates inform us, that camera has a 24 bits color depth, which means it can distinguish 16777215 different colors with a maximal resolution of $640 \times 480$ pixels and 15 frames per second. This frequency of image acquire is not elevated, but enough for the image recognition process.

According to the manual, the process of color recognition is made using a cylindrical coordinates and the colors are inside the visible light spectrum, from 400 [nm] until 700 [nm].

\section{Regulation Design}

The Control diagram of the regulation can be seen on Fig. 2. It is clearly visible, that whole control process is arranged on PC, from where the curtain moving motor and LED control circuit is directed, through the $1 / 2$ De-Multiplexer.

\section{Conclusion}

In this paper a possible concept for the brightness stabilization in the iRoom, laboratory has been introduced. The whole con- trol program is located on $\mathrm{PC}$, what is communicating by the peripheries through Wi-Fi or Bluetooth.

\section{Acknowledgements}

This paper was developed during the exchange program Science without Borders, supported by the Brazilian government.

This work was also sponsored by the Hungarian National Scientific Fund (OTKA 105846)

\section{References}

[1] A.R.Várkonyi-Kóczy, I. Nagy, I. Langer, E. Tóth-Laufer: Intelligent Space: New Challenges in Research and Education, in Proc. of INES2013, 17th International Conference on Intelligent Engineering Systems, Costa Rica, PP.: 357-364, 2013

[2] A.R.Várkonyi-Kóczy, I. Nagy, I. Langer, E. Tóth-Laufer: Research Activities int he Intelligent Space Laboratory of the Óbuda University, in Proc. of 1st Regional Conference, Mechatronics in Practice and Education, MECH-CONF2011, ISBN 978-86-85409-677, Serbia, Subotica, PP.. 411-422, 2011. 